\title{
HIDALGO GARCÍA DE ORELLÁN, Sara y COMONTE SANTAMARÍA, Ángel, Resistencia socialista en femenino. Violencia de ETA y mujeres del PSE desde la Transición hasta 2011, Catarata, Madrid, 2020. 240 pp.
}

Sara Hidalgo y Ángel Comonte aportan, con esta original obra, una visión muy necesaria de la violencia de ETA desde la perspectiva de las mujeres socialistas vascas cuya experiencia ha sido invisibilizada en relación con la de los hombres. Mujeres socialistas dedicadas a la política activa con puestos destacados en ayuntamientos, el Gobierno Vasco o las Juntas Generales, pero también militantes de base o familiares - esposas, hermanas, hijas, madres - de cargos públicos que lucharon por la democracia. Se trata de una reivindicación de estas mujeres como «arquitectas de la libertad», como contribuyentes a la consolidación de la democracia en Euskadi y al fin del terrorismo desde su labor en las instituciones.

Sus autores, Sara Hidalgo García de Orellán (Doctora en Ciencias Políticas por la Universidad de Santiago de Compostela) y Ángel Comonte Santamaría (Licenciado en Historia Contemporánea por la Universidad de Deusto), poseen una amplia trayectoria en el estudio del socialismo vasco que ahora completan con esta investigación dedicada a las mujeres resistentes vascas.

Se basan para ello en una metodología que aúna historia y memoria, con el uso de fuentes documentales y también entrevistas para dar respuestas al cómo del sentimiento socialista. En este sentido, la historia oral es clave para reconstruir el impacto del pasado terrorista sobre las socialistas vascas a través de sus «relatos de vida», de sus «verdades subjetivas», del cómo esas mujeres vivenciaron y significaron un determinado momento histórico, en este caso el terrorismo etarra. Una metodología novedosa en el estudio del impacto de la violencia de ETA que otorga originalidad a la obra.

Así, el libro que tenemos entre manos se divide en cuatro capítulos. El primero de ellos, bajo el título La Euskadi del terrorismo etarra (1959-2011), nos acerca sucintamente a los orígenes de ETA en 1959. A lo largo de estas primeras páginas, los autores realizan un recorrido por la historia de ETA destacando los hitos fundamentales en relación con el socialismo vasco. Se concede especial atención a los primeros asesinatos de socialistas vascos a finales de los setenta y comienzos de los años ochenta y a la indiferencia mostrada por la inmensa mayoría de la sociedad vasca. Los autores continúan este recorrido adentrándonos en los años noventa, en los que el debilitamiento de la banda puso en juego una nueva estrategia, la llamada «socialización del sufrimiento». Una ofensiva hacia todos los ámbitos de la política y de la vida social que ya no buscaba únicamente matar sino atemorizar. Tal y como van desgranando con un reguero de testimonios de víctimas de este tipo de violencia, la persecución (coacción, desgaste diario, amenazas, etc.) se convirtió en el pan nuestro de cada día para miles de vas- 
cos y vascas. Una violencia invisibilizada que trató de estigmatizar y aislar a las víctimas como parte de su mensaje de abstención al resto de la sociedad. Políticos socialistas como Estanis Amuchástegui, Izaskun Gómez, Arritxu Marañón o José Luis Vela dan buena cuenta a través de sus testimonios de la tremenda fractura política y social que provocaron aquellos innumerables actos de kale borroka. Se trata, en definitiva, de una breve contextualización del terrorismo en Euskadi con los y, sobre todo, las socialistas como protagonistas para comprender los capítulos posteriores.

El segundo capítulo, Las mujeres socialistas de la Transición: de la lucha y resistencia antifranquista al totalitarismo de ETA, pretende resaltar el papel de las mujeres socialistas, aquellas que contribuyeron a la reconstrucción del PSOE en el País Vasco y que sufrieron la persecución de ETA y toda su órbita. El capítulo comienza con un estado de la cuestión acerca de la escasez en los estudios sobre estas mujeres en comparación con otras investigaciones sobre el socialismo español. Los autores continúan con un repaso por el papel de las resistentes vascas durante los años del franquismo como María Begoña Álvarez Bazán, Nati Terreros, Tina Díaz Azcona, Alicia Ayala, Esther Cabezudo, Lentxu Rubial y un largo etc. Mujeres que lucharon contra el régimen, vivieron en la clandestinidad, fueron perseguidas e incluso sufrieron penas de cárcel. Para después, ya en democracia, enfrentarse al terror de ETA. Como expresan los autores, aquellas mujeres siguieron construyendo país desde lo que llaman «socialismo de lo pequeño», convirtiéndose en grandes figuras históricas.

El tercero, que lleva por título Mujer y resistencia en Vizcaya, está dedicado a los relatos y reflexiones de las militantes socialistas vizcaínas. Se sirven en concreto de los ejemplos de dos mujeres: el de Maite Torrano y el de Esther Cabezudo, para ilustrar las agresiones que se vivieron en aquellos años. La primera murió en el ataque con cocteles molotov a la Casa del Pueblo de Portugalete en abril de 1987; mientras que la segunda sobrevivió a un atentado con un carrito bomba también en Portugalete en febrero de 2002. Los testimonios de todas ellas, entre los que destacan las reflexiones de Estíbaliz Freije Rueda, Loly de Juan de Miguel, Eider Gardiazábal Rubial, Itziar Cordón Gutiérrez, Marian Muñoz Llamas o Idoia Mendia Cueva, reflejan el sufrimiento vivido.

Por último, el cuarto apartado, Guipúzcoa y Álava. Realidades diferentes, misma persecución del terrorismo, se centra en la realidad de estas dos provincias. Guipúzcoa ha sido la provincia vasca más castigada por el terrorismo, tanto en lo que se refiere a víctimas mortales como a persecución y ataques de kale borroka. Como recogen diferentes testimonios de socialistas guipuzcoanas - como Rafaela Romero, Soledad del Bosque, Izaskun Gómez, Estefanía Morcillo o Arritxu Marañón-, el día a día de la mayoría de los cargos públicos no nacionalistas era una tortura en aquellos pueblos de apenas unos pocos miles de habitantes. Insultos, amenazas, agresiones diarias en los ayuntamientos de mayoría abertzale, pero también a sus familias y a sus negocios. Y, pese a todo, siguieron resistiendo 
y contestando en honor al compromiso que habían adquirido con sus votantes y en memoria del partido, lo que los autores denominan «código de libertad». Cierran el capítulo con la parte dedicada a Álava, con el protagonismo del gran líder del socialismo alavés, Fernando Buesa Blanco. Con su asesinato en el año 2000, su viuda, Natividad Rodríguez, y sus hijas, Marta y Sara, surgieron en el espacio público para rememorar su figura, desmitificar el ideario abertzale tan popular entre la juventud vasca de aquellos años y deslegitimar el terrorismo. Junto a ellas también destaca Esozi Leturiondo, compañera de Mario Onaindia, continuando su labor en la lucha por la libertad.

Como decía al principio, se trata de un estudio muy necesario para entender la experiencia vivida por un grupo político concreto, en este caso el socialista, pero que se puede extender perfectamente al resto de los grupos democráticos que padecieron situaciones similares frente a la violencia terrorista de ETA. Así, la historia de las mujeres socialistas vascas frente a ETA se hace fundamental para comprender la historia reciente de Euskadi. Sus memorias y reflexiones son imprescindibles para conocer su sufrimiento y deslegitimar el relato que asume que la lucha armada fue necesaria.

Alejandra Ibarra Aguirregabiria 